\title{
INTEGRASI PASAR MODAL KAWASAN CINA - ASEAN
}

\author{
Budi Santosa \\ Fakultas Ekonomi Universitas Trisakti Jakarta \\ Jalan Kyai Tapa No.1 Grogol Jakarta Barat, Telp: 021-5663232 \\ E-mail: busan_228@yahoo.com
}

Diterima 30 Desember 2012 / Disetujui 9 April 2013

\begin{abstract}
This study aims to analyze the level of capital market integration ASEAN and China. Analysis tool used is Vector Error Correction Model (VECM). The results showed that capital markets of Malaysia, Philippines, Singapore, Thailand, and China have a positive effect on Indonesian capital markets, but the Indonesian capital market does not affect the capital markets of other countries. Singapore capital market has a positive effect on capital markets of Indonesia, Malaysia, Thailand, and China, except for the Philippines. China's capital market only affects the capital market in Singapore. Singapore capital market and China have complete integration because both affect each other. Philippine capital market only affects Indonesian capital market. Indonesian capital market is easily influenced by the fluctuation in capital markets in the ASEAN region and China. Singapore capital market is in a strong position. While the Philippine capital market are relatively more segmented.
\end{abstract}

Keywords : ACFTA, capital market, integration, co-integration, Vector Correction Model JEL: F36

\begin{abstract}
Abstrak: Penelitian ini bertujuan untuk menganalisis tingkat integrasi pasar saham kawasan ASEAN dan China. Alat analisis yang digunakan adalah Model Vector Correction Model (VECM). Hasil penelitian menunjukkan bahwa pertama, pasar modal Malaysia, Filipina, Singapura, Thailand, dan China berpengaruh positif terhadap pasar modal Indonesia, tetapi pasar modal Indonesia tidak berpengaruh terhadap pasar modal negara lain. Kedua, pasar saham Singapura berpengaruh positif terhadap pasar modal Indonesia, Malaysia, Thailand, dan China, kecuali Filipina. Ketiga, pasar modal China hanya mempengaruhi pasar modal di Singapura. Pasar saham Singapura dan China mengalami integrasi lengkap karena keduanya saling mempengaruhi. Keempat, pasar modal Filipina hanya mempengaruhi pasar modal Indonesia. Pasar modal Indonesia berada dalam posisi rentan, mudah dipengaruhi oleh gejolak pasar modal yang terjadi di kawasan ASEAN dan China. Pasar modal Singapura berada dalam posisi yang kuat, sebagai referensi untuk pasar modal lain di wilayah tersebut. Sementara pasar modal Filipina relatif lebih tersegmentasi, dipengaruhi gejolak domestik.
\end{abstract}

Kata kunci: ACFTA, pasar modal, integrasi, co-integrasi, Vector Correction Model JEL: F36

\section{PENDAHULUAN}

Sebuah terobosan telah dilakukan oleh komunitas masyarakat regional di kawasan ASEAN (Assosiation of South East Asia Nations) dan China dengan membentuk komunitas perdagangan bebas, yakni melalui perjanjian ASEAN China Free Trade Area (ACFTA). ACFTA ini menimbulkan suatu perkembangan baru pada kegiatan perdagangan internasional, terutama pada kawasan Asia Tenggara. Kesiapan menyambut dampak positif dan negatif dari terselenggaranya ACFTA, menjadi problematika tersendiri yang menarik untuk dicermati terutama di Negara Indonesia sebagai salah satu negara yang memiliki potensi comparative advantage.

Investasi ke dalam dan ke luar negeri dalam konteks ACFTA merupakan peluang 
yang memiliki dua sisi yang berlawanan, menjanjikan atau justru merugikan. Indonesia dengan segala potensinya dihadapkan pada sebuah tantangan untuk dapat bertahan dan meningkatkan posisinya didalam perdagangan dan investasi. Namun bagi masyarakat di Indonesia, muncul pro-kontra tentang kemampuan dan kesiapan investasi di Indonesia dalam menghadapi era perdagangan bebas versi ACFTA ini.

Persetujuan Jasa ACFTA ditandatangani pada pertemuan ke-12 KTT ASEAN di Cebu, Filipina, Januari 2007. Sedangkan Persetujuan Investasi ASEAN China ditandatangani pada saat pertemuan ke-41 Tingkat Menteri Ekonomi ASEAN, pada tanggal 15 Agustus 2009 di Bangkok, Thailand. Oleh karena telah disahkannya ACFTA secara formal, maka Indonesia perlu untuk menyesuaikan diri dengan hal-hal yang diperjanjikan dalam ACFTA.

Pemberlakuan ACFTA di Indonesia memiliki sisi positif dan negatif bagi masyarakat khususnya para pelaku usaha. Kenyataan yang mau tidak mau harus dihadapi adalah, masingmasing pemerintah sudah membuat kesepakatan ACFTA. Dengan telah ditandatanganinya kesepakatan ini melalui tahap demi tahap sejak lama, masyarakat Indonesia mau tidak mau haruslah siap menerima diberlakukannya kesepakatan ACFTA tersebut. Pelaksanaan ACFTA seharusnya tidak menjadi momok bagi masyarakat Indonesia, tetapi hendaklah menjadi memacu untuk bekerja lebih keras. Memang tidak dapat disangkal bahwa di satu sisi kesepakatan tersebut akan banyak menguntungkan bagi para konsumen. Sementara di sisi lain juga dapat mengancam kelangsungan hidup produsen lokal. Hal tersebut menyebabkan kegelisahan masyarakat dalam negeri. Maka nampak banyak pihak di Indonesia yang bereaksi, namun jika ditelusuri lebih jauh bisa diartikan sebagai sikap yang tidak siap; karena sejak beberapa tahun terakhir ini belum merasa banyak langkah-langkah persiapan menyongsong ACFTA.

Berkaitan dengan pembentukan ACFTA tersebut, maka yang menarik untuk diamati lebih lanjut adalah tentang perkembangan pasar modal di kawasan ASEAN dan Cina. Pasar modal adalah pertemuan antara supply dan demand akan dana jangka panjang, yang diwujudkan dalam bentuk instrumen-instrumen keuangan yang bisa diperjualbelikan. Dengan adanya pasar modal internasional, para pemodal bisa melakukan investasi di berbagai negara bukan untuk melakukan investasi langsung (direct investment), seperti yang dilakukan oleh perusahaan-perusahaan multinasional dan transnasional, tetapi dengan jalan membeli sekuritas-sekuritas yang ditawarkan di bursabursa efek tersebut.

Kerjasama pasar modal yang lebih erat intra kawasan ASEAN dan Cina tentunya akan meningkatkan peran pasar modal dalam pembangunan ekonomi negara-negara ASEAN dan Cina. Permasalahan yang terjadi adalah seberapa dekat keterkaitan antarpasar modal di negara-negara ASEAN dan Cina, atau secara spesifik masalahnya adalah bagaimana tingkat integrasi dan kecenderungannya dari pasar saham di negara-negara ASEAN dan Cina. Apakah pasar modal di kawasan ASEAN dan Cina memang sudah terintegrasi? Pasar modal mana sajakah yang mempengaruhi dan pasar modal mana sajakah yang dipengaruhi di antara pasar modal di kawasan ASEAN dan Cina tersebut secara signifikan?

Bentuk Kerjasama Regional. Negaranegara yang bergerak dalam perdagangan internasional telah membentuk suatu persekutuan dagang yang sebelumnya telah terjadi hubungan antarnegara yang istimewa. Bentuk kerjasama regional dapat dibagi menjadi empat kategori yaitu Trade Prefential Agreement (TPA), Free Trade Area, Customs Union, Common Market, Economic Union dan Monetary Union (MU) (Hady, 2004).

Trade Prefential Agreement (TPA) merupakan tahapan paling awal dari bentuk kerjasama regional. TPA adalah kerjasama ekonomi regional dimana masing-masing anggota memberikan preferensi dalam bentuk tarif dan nontarif bagi produk orisinal masing-masing negara atau dengan kata lain fasilitas keringanan bagi satu atau beberapa produk tertentu dari negara partner. Kedua adalah Free Trade Area (FTA) adalah suatu bentuk kerjasama regional yang menghilangkan sampai 0 persen bea masuk bagi semua produk dari negara anggota dan memberlakukan tarif bagi negara bukan 
anggota regional. Secara sederhana dapat dipahami bahwa internal tarif antaranggota sudah tidak ada namun eksternal tarif masingmasing negara tetap berlaku, contoh AFTA (ASEAN Free Trade Area). Ketiga adalah Custom Union $(\mathrm{CU})$ atau penyatuan kepabeanan adalah kerjasama regional dimana penerimaan bea dan cukai atau custom revenue tiap-tiap anggota yang didapat dari negara di luar anggota dianggap sebagai penerimaan bersama (kolektif), oleh karena itu eksternal tarif di setiap negara anggota sama bagi suatu produk luar regional. Sedangkan internal tarif antar anggota sebesar 0 persen. Keempat adalah Common Market (CM) merupakan salah satu bentuk kerjasama yang mengusung kebebasan bergerak bagi faktor produksi, khususnya tenaga kerja, dalam kerjasama regional tersebut. Contoh European Common Market. Kelima adalah Economic Union $(E U)$ maksudnya adalah bentuk kerjasama ekonomi regional yang memiliki kesatuan atau persamaan peraturan dalam bidang perpajakan, tenaga kerja, jaminan sosial, dan lain-lain. Contoh Economic Union seperti CAEC (Concil of Arab Economic Community). Keenam adalah Monetary Union $(M U)$ adalah kerjasama regional yang berbentuk kesatuan atau kesamaan mata uang, contoh European Community yang memiliki mata uang tuggal resmi sejak 1 Januari 1999 yakni Euro (Hady, 2004).

ACFTA (ASEAN-Cina Free Trade Agreement). Perjanjian yang menyepakati adanya ASEAN-China Free Trade Agreement (ACFTA) sebenarnya sudah direncanakan sejak lama. Kesepakatan pembentukan perdagangan bebas ACFTA diawali oleh kesepakatan para peserta ASEAN-China Summit di Brunei Darussalam pada November 2001. Hal tersebut diikuti dengan penandatanganan Naskah Kerangka Kerjasama Ekonomi (The Framework Agreement on A Comprehensive Economic Cooperation) oleh para peserta ASEAN-China Summit di Pnom Penh pada November 2002, dimana naskah ini menjadi landasan bagi pembentukan ACFTA dalam 10 tahun dengan suatu fleksibilitas diberikan kepada negara tertentu seperi Kamboja, Laos, Myanmar dan Vietnam (Indonesian CRI, 2010).

Setahun kemudian, pada November 2002
Pertemuan Pemimpin China-ASEAN ke-6 diadakan di Phnom Penh, Ibu Kota Kamboja. Perdana Menteri Zhu Rongji dan pemimpin 10 Negara ASEAN menandatangani Persetujuan Kerangka Kerjasama Ekonomi China-ASEAN (Framework Agreement on Comprehensive Economic Cooperation between the ASEAN and People's Republic of China). Dengan demikian zona perdagangan bebas China-ASEAN diputuskan akan diresmikan pada tahun 2010.

Pada November 2004, China dan ASEAN menandatangani persetujuan pengurangan tarif pada sekitar 7.000 komoditi tertentu yang akan dimulai pada Juli 2005. Pada 14 Januari 2007, China dan ASEAN menandatangani Persetujuan Perdagangan Pelayanan. Kedua pihak berkomitmen saling membuka pasar masingmasing.

Pada 15 Agustus 2009, China dan ASEAN menandatangani Persetujuan Investasi Kawasan Perdagangan Bebas China-ASEAN. Peristiwa tersebut menandakan selesainya perundingan utama pembentukan kawasan perdagangan bebas China-ASEAN, dan zona tersebut akan dirampungkan secara menyeluruh pada tahun 2010.

Pada 25 Oktober 2009, dalam Pertemuan Puncak Asia Timur ke-4, China dan ASEAN menandatangani MoU Kerjasama China dan ASEAN di bidang HAKI dan MoU mengenai peraturan teknik dan standar prosedur pengevaluasian sertifikasi.

Pada 1 Januari 2010, ACFTA efektif. Sejak 1 Januari 2010, perjanjian perdagangan bebas antara China dan enam negara anggota ASEAN (Indonesia, Thailand, Malaysia, Singapura, Filipina, dan Brunei Darussalam) yang lebih dikenal dengan ASEAN China Free Trade Agreement (ACFTA) telah dimulai. Program penurunan tarif bea masuk dalam website Direktorat Jenderal KPI Departemen Perdagangan Republik Indonesia dituliskan bahwa program menurunkan tarif bea masuk dilakukan melalui 3 (tiga) tahap, yaitu: Tahap I adalah Early Harvest Program (EHP); Tahap II adalah Normal Track I dan II; dan Tahap III adalah Sensitive/Highly Sensitive List (http:/ / www.ditjenkpi.go.id).

Program penurunan tarif bea masuk dalam kerangka Perdagangan Bebas ASEAN-China, dilakukan secara bertahap dimulai pada 1 
Januari 2004 untuk EHP dan menjadi 0 persen pada 1 Januari 2006; kemudian dimulai tanggal 20 Juli 2005 untuk Normal Track, yang menjadi 0 persen pada tahun 2010; dengan fleksibilitas pada produk-produk yang akan menjadi 0 persen pada tahun 2012. Produk-produk dalam kelompok Sensitive, akan dilakukan penurunan tarif mulai tahun 2012, dengan penjadwalan bahwa maksimun tarif bea masuk pada tahun 2012 adalah 20 persen dan akan menjadi 0-5 persen mulai tahun 2018. Produk-produk Highly Sensitive akan dilakukan penurunan tarif bea masuk pada tahun 2015, dengan maksimum tarif bea masuk pada tahun 2015 sebesar 50 persen. Jadi tidak benar kalau ada pemahaman bahwa penurunan dan penghapusan tarif bea masuk dalam Perdagangan Bebas ASEANChina dilakukan serentak atas seluruh produk mulai 20 Juli 2005.

Integrasi Pasar modal. Sejumlah besar penelitian telah dilakukan pada masalah integrasi pasar modal. Dalam hal ini, berbagai indikator telah dikembangkan untuk mengukur tingkat integrasi. Faktor umum yang mendasari hal tersebut adalah adanya hukum satu harga/ Law Of One Price (LOOP), yang merupakan prinsip fundamental integrasi pasar keuangan. Hukum tersebut menyatakan bahwa dengan tidak memperhitungkan biaya transaksi dan pajak, surat-surat berharga yang sama harus pula memiliki harga yang sama di semua pasar modal di mana sekuritas tersebut diperdagangkan. Dengan kata lain, jika terdapat dua atau lebih pasar modal yang terintegrasi, maka aset dengan arus kas yang identik harus memberikan return yang sama di kedua pasar. Dalam kasus integrasi pasar modal, semua aset yang memiliki karakteristik risiko dan jatuh tempo yang sama memiliki potensi untuk memberikan return yang sama di pasar yang berbeda. Selain itu, dengan tidak adanya hambatan yang menghasilkan premi risiko negara dan nilai tukar, aset keuangan dengan risiko dan likuiditas yang sama diharapkan mencapai hasil yang sama pula, terlepas dari kebangsaan atau lokasi (Von Furstenberg dan Jeon, 1989; Narayan et al, 2004; Marashdeh dan Shrestha, 2010).

Salah satu implikasi penting dari adanya hubungan jangka panjang antar pasar modal internasional adalah untuk diversifikasi porto- folio dan manajemen. Terdapat hubungan terbalik antara manfaat dari diversifikasi portofolio dan tingkat integrasi pasar saham. Oleh karena itu, kurangnya kointegrasi antara pasar modal memungkinkan investor untuk meminimalkan risiko portofolio dengan diversifikasi antara pasar saham (Kearny dan Lucey, 2004).

Pengukuran integrasi pasar modal dikategorikan menjadi tiga aliran utama: menggunakan model harga aset modal internasional/ International Capital Asset Pricing Model (ICAPM), dengan menurunkan pengukuran variasi waktu dari integrasi dan menggunakan pendekatan kointegrasi. Berlawanan dengan CAPM, yang mengasumsikan bahwa pasar tersegmentasi secara sempurna, ICAPM umumnya mengasumsikan pasar terintegrasikan dengan sempurna. Menurut model ini, pasar modal internasional dianggap terintegrasi jika sekuritas dengan karakteristik risiko sama dihargai pada tingkat yang sama pula, bahkan jika mereka diperdagangkan di pasar yang berbeda.

Beberapa studi yang menggunakan ICAPM sebagai ukuran integrasi pasar modal adalh Solink (1974), Stulz (1981), Adler dan Dumas (1983), Jorion dan Schwartz (1986) dan Buckberg (1995). Buckberg (1995) menggunakan data bulanan selama periode 1977-1991 untuk dua puluh pasar modal di negara berkembang untuk menganalisis pola integrasi. Hasil studi itu menunjukkan bahwa tersapat delapan belas dari dua puluh pasar modal yang terintegrasi dengan pasar modal dunia selama periode 1984-1991. Alasan utama untuk integrasi ini adalah adanya arus masuk modal yang besar dari negara-negara industri ke pasar-pasar modal negara sedang berkembang selama 1980an. (Marashdeh dan Shrestha, 2010).

Penelitian sebelumnya. Bekaert dan Harvey (1995) mengembangkan metodologi ekonometrik yang inovatif dengan menggunakan model rezim-switching bersyarat (conditional regimeswitching model). Metodologi ini memungkinkan untuk tingkat integrasi pasar modal yang berubah sepanjang waktu. Hal ini juga memungkinkan untuk beralih antara segmentasi dan integrasi dengan memberikan probabilitas untuk model penentuan harga aset masingmasing. Studi ini menggunakan data dari 12 negara berkembang dan 21 pasar modal yang 
dikembangkan selama periode 1975-1992. Ia menemukan bahwa beberapa pasar modal negara berkembang menunjukkan integrasi dalam waktu yang bervariasi, sedangkan yang lain tampaknya lebih terintegrasi dari yang diharapkan, sementara lainnya lagi lebih tersegmentasi meskipun ada akses bebas ke pasar modal mereka. Studi ini menunjukkan bahwa bukan suatu kasus bahwa dunia pasar modal telah menjadi lebih terintegrasi. Meskipun penghapusan atau relaksasi dari pembatasan kepemilikan saham asing oleh sejumlah negaranegara berkembang pada tahun 1990, hanya 4 dari 12 negara memiliki ukuran integrasi yang lebih tinggi pada periode yang sama.

Sebagian besar studi terbaru telah menggunakan pendekatan kointegrasi untuk menilai tingkat integrasi di pasar modal. Salah satu keistimewaan harga saham adalah bahwa selama periode yang lama mereka cenderung untuk bergerak bersama dan mengikuti tren umum (Azman-Saini et al., 2002). Banyak penelitian mencoba untuk menentukan jumlah tren stokastik yang umum. Jika pasar modal yang terintegrasi, maka diharapkan untuk indeks di pasar-pasar untuk menampilkan tren yang sama. Adanya pergerakan bersama antara harga sekuritas menunjukkan integrasi pasar saham. Pergerakan bersama Ini menyiratkan bahwa salah satu pasar akan membantu memprediksi pendapatan pasar lainnya, karena akan ada representasi koreksi kesalahan.

Kasa (1992), yang merupakan salah satu studi awal yang menggunakan pendekatan kointegrasi untuk mengukur integrasi pasar modal, menemukan bahwa terdapat lima negara industri utama yang berkorelasi sempurna dalam waktu yang panjang, yang berarti bahwa tidak ada keuntungan dari diversifikasi internasional. Darrat et al. (2000) menggunakan pendekatan kointegrasi Johansen-Juselius untuk mengeksplorasi pola dan sejauh mana tiga pasar saham yang berkembang di kawasan MENA (yaitu Mesir, Maroko dan Yordania) dihubungkan antara mereka sendiri dan dengan pasar saham internasional. Mereka menemukan bahwa pasar MENA tersegmentasi secara global dan terintegrasi secara regional. Neaime (2002) menggunakan pendekatan kointegrasi Engle-Granger untuk menganalisis inte- grasi pasar modal di kalangan pasar saham di kawasan MENA dan antara pasar-pasar dan pasar negara maju. Studi ini juga menemukan integrasi yang lemah antara pasar MENA dan integrasi yang kuat antara pasar modal negara maju. Marashdeh (2005) menggunakan pendekatan kointegrasi ARDL untuk menguji integrasi keuangan di kawasan MENA. Hasil penelitian menunjukkan bahwa terdapat hubungan keseimbangan jangka panjang di antara semua pasar saham di kawasan MENA, tapi tidak dengan pasar negara maju.

Peneliti-peneliti lain seperti Yang et al. (2003), Narayan et al. (2004), dan Febrian dan Herwany (2007) dan Choudhry et al. (2007) menggunakan pendekatan kointegrasi yang berbeda untuk mengukur integrasi pasar modal di antara beberapa pasar modal di Asia. Mereka melaporkan hasil yang beragam mengenai adanya integrasi di antara pasar-pasar modal tersebut dan di antara pasar-pasar modal negara berkembang dengan negara maju seperti Amerika Serikat dan Jepang.

Assaf (2003), meneliti hubungan antara return pasar saham dari enam negara Gulf Cooperation Council (GCC) dengan menggunakan model VAR pada data mingguan selama periode 1997 hingga 2000 dan menemukan bukti substansial dari saling ketergantungan antara pasar GCC.

Endri (2009), menginvestigasi integrasi pasar saham di negara-negara kawasan ASEAN5 yaitu Indonesia, Singapura, Malaysia, Thailand, dan Filipina plus China dalam mendukung kawasan perdagangan bebas ASEANChina (ACFTA) menggunakan data indeks harga saham harian selama periode 2 Januari 2003 sampai 31 Desember 2009. Studi ini mengaplikasikan teknik kointegrasi Johansen untuk mendeteksi dan mengidentifikasi hubungan dinamis jangka panjang (kointegrasi) pasar saham ASEAN-5 plus China. Temuan empiris menunjukkan bahwa derajat integrasi baik pasar saham negara-negara ASEAN-5 saja maupun ASEAN-5 plus China masih rendah, dimana hanya terdapat satu vektor yang terkointegrasi secara signifikan. Oleh karena itu, dapat kita katakan bahwa pasar saham ASEAN-5 plus China terintegrasi dalam arti ekonomi (economic sense), tetapi belum secara sempurna. Atau 
dengan kata lain, derajat integrasi pasar saham antar negaranegara kawasan ASEAN-5 plus China masih rendah.

\section{METODE PENELITIAN}

Tujuan penelitian adalah untuk mengetahui dan membuktikan adanya integrasi pasar modal di ASEAN dan Cina. Dalam penelitian ini analisis data dilakukan dalam beberapa langkah, yang akan dijelaskan sebagai berikut:

\section{Deteksi Stasioneritas: Uji Akar Unit}

Dalam Widarjono (2007) dikatakan bahwa data time series seringkali tidak stasioner sehingga menyebabkan hasil regresi yang meragukan atau sering disebut regresi lancung (superious regression). Regresi lancung adalah situasi dimana hasil regresi menunjukkan koefisien regresi yang signifikan secara statistik dan nilai koefisien determinasi yang tinggi namun hubungan antarvariabel di dalam model tidak saling berhubungan. Data yang tidak stasioner seringkali menunjukkan hubungan ketidakseimbangan dalam jangka pendek, tetapi ada kecenderungan terjadinya hubungan keseimbangan dalam jangka panjang. Agar regresi yang dihasilkan tidak rancu (meragukan) kita perlu merubah data tidak stasioner menjadi data stasioner.

Setiap data time series merupakan suatu data dari hasil proses stokastik atau bersifat random. Suatu data hasil proses random dikatakan stasioner jika memenuhi tiga kriteria, yaitu jika rata-rata dan variannya konstan sepanjang waktu dan kovarian antara dua data runtut waktu hanya tergantung dari kelambanan (lag) antara dua periode waktu tersebut. Misalkan kita bergerak dari data time series $Y$ dari $Y_{t}$ ke $Y_{t+m}$. Jika data $Y_{t}$ adalah stasioner maka rata-rata, varian dan kovarian dari data $\mathrm{Y}_{\mathrm{t}+\mathrm{m}}$ harus sama dengan data $\mathrm{Y}_{\mathrm{t}}$, artinya pada setiap lag adalah tetap sama pada setiap waktu. Data time series dikatakan tidak stasioner jika rata-ratanya maupun variannya tidak konstan, berubah-ubah sepanjang waktu (time-varying mean and variance). Secara statistik dapat dinyatakan sebagai berikut:
$\mathrm{E}\left(\mathrm{Y}_{\mathrm{t}}\right)=\mu$ yakni rata-rata dari $\mathrm{Y}$ konstan

$\operatorname{Var}\left(\mathrm{Y}_{\mathrm{t}}\right)=\mathrm{E}\left(\mathrm{Y}_{\mathrm{t}^{-}} \mu\right)^{2}=\sigma^{2}$ yakni varian dari $\mathrm{Y}$ konstan

$\gamma \mathrm{k}=\mathrm{E}\left[\left(\mathrm{Y}_{\mathrm{t}^{-}} \mu\right)\left(\mathrm{Y}_{\mathrm{t}+\mathrm{k}^{-}} \mu\right)\right]$ yakni kovarian $\gamma_{\mathrm{k}}$ pada kelambanan (lag) $\mathrm{k}$ adalah kovarian antara nilai $Y_{t}$ dan $Y_{t+k}$.

Metode uji stasioneritas dilakukan dengan uji akar-akar unit (unit root test). Uji akar unit yang sekarang terkenal adalah uji dari Dickey Fuller (DF) dan Phillips Perron (PP), namun yang biasa digunakan adalah uji DF karena uji ini sangat sederhana. Uji yang dilakukan dengan menggunakan Uji Augmented DickeyFuller (ADF). Adapun formulasi uji ADF adalah sebagai berikut:

$$
\begin{aligned}
& \Delta Y_{t}=\gamma Y_{t-1}+\sum_{i=2}^{p} \beta_{i} \Delta Y_{t-1+1}+e_{t} \\
& \Delta Y_{t}=a_{0}+\gamma Y_{t-1}+\sum_{i=2}^{p} \beta_{i} \Delta Y_{t-1+1}+e_{t} \\
& \Delta Y_{t}=a_{0}+a_{1} T+\gamma Y_{t-1}+\sum_{i=2}^{p} \beta_{i} \Delta Y_{t-1+1}+e_{t}
\end{aligned}
$$

dimana $Y$ adalah variabel yang diamati, $\Delta Y_{t}=Y_{t}$ - $Y_{t-1}$, dan T adalah trend waktu.

Prosedur untuk menentukan apakah data stasioner atau tidak dengan cara membandingkan antara nilai statistik ADF (Augmented Dickey-Fuller) dengan nilai kritis distribusi statistik Mackinnon. Nilai statistik ADF ditunjukkan oleh nilai $\mathrm{t}$ statistik koefisien $\gamma \mathrm{Y}_{\mathrm{t}-1}$ pada persamaan-persamaan di atas. Jika nilai absotut statistik ADF Iebih besar dan nilai kritisnya, maka data yang diamati menunjukkan stasioner dan jika sebaliknya nilai absolut statistik ADF Iebih kecil dan nilai kritisnya maka data tidak stasioner.

Data tidak stationer dapat dijadikan menjadi data stationer melalui proses diferensi data. Uji stasioner data melalui proses diferensi ini disebut uji derajat integrasi. Adapun formulasi uji derajat integrasi dari ADF sebagai berikut:

$$
\begin{aligned}
& \Delta 2 Y_{t}=\gamma Y_{t-1}+\sum_{i=2}^{p} \beta_{i} \Delta 2 Y_{t-1+1}+e_{t} \\
& \Delta 2 Y_{t}=a_{0}+\gamma \Delta Y_{t-1}+\sum_{i=2}^{p} \beta_{i} \Delta 2 Y_{t-1+1}+e_{t} \\
& \Delta 2 Y_{t}=a_{0+} a_{1} T+\gamma \Delta Y_{t-1}+\sum_{i=2}^{p} \beta_{i} \Delta 2 Y_{t-1+1}+e_{t}
\end{aligned}
$$


Seperti uji akar-akar unit sebelumnya, keputusan sampai pada derajat keberapa suatu data akan stasioner dapat dilihat dengan membandingkan antara nilal statistik ADF yang diperoleh dan koefisien $\gamma$ dengan nilai kritis distribusi statistik Mackinnon. Jika nilai absolut dan statistik ADF lebih besar dari nilai kritisnya pada diferensi tingkat pertama, maka data dikatakan stasioner pada derajat satu. Akan tetapi, jika nilainya lebih kecil maka uji derajat integrasi perlu dilanjutkan pada diferensi yang lebih tinggi sehingga diperoleh data yang stasioner.

\section{Uji Kointegrasi}

Regresi yang menggunakan data time series yang tidak stasioner kemungkinan besar akan menghasilkan regresi lancung. Regresi lancung terjadi jika koefisien determinasi cukup tinggi tapi hubungan antara variabel independen dan variabel dependen tidak mempunyai makna. Hal ini terjadi karena hubungan keduanya yang merupakan data time series hanya menunjukkan tren saja, bukan karena hubungan keduanya.

Secara umum bisa dikatakan bahwa jika data time series $\mathrm{Y}$ dan $\mathrm{X}$ tidak stasioner pada tingkat level (aras) tetapi menjadi stasioner pada tingkat diferensi pertama atau diferensi (difference) yang sama yaitu $\mathrm{Y}$ adalah $\mathrm{I}(d)$ dan $\mathrm{X}$ adalah $\mathrm{I}(d)$ dimana $d$ tingkat diferensi yang sama maka kedua data adalah terkointegrasi (mempunyai hubungan dalam jangka panjang). Jadi, uji kointegrasi hanya bisa dilakukan ketika data yang digunakan dalam penelutuan berintegrasi pada derajat yang sama.

Alternatif uji kointegrasi yang sekarang banyak digunakan adalah uji kointegrasi yang dikembangkan oleh Johansen. Uji yang dikembangkannya dapat digunakan untuk menentukan kointegrasi sejumlah variabel (vektor), dengan model autoregresif dengan order $p$ berikut ini:

$$
Y_{t}=A_{1} Y_{t-1}+\ldots .+A_{p} Y_{t-p}+\mathrm{B} X_{t}+\varepsilon_{t}
$$

dimana Yt adalah vektor $\mathrm{k}$ dari variabel $\mathrm{I}(1)$ non-stokastik, $\mathrm{Xt}$ adalah vektor $\mathrm{d}$ dari variabel deterministic, dan $\varepsilon_{\mathrm{t}}$ adalah vektor inovasi.

Untuk menjelaskan ada tidaknya kointe- grasi dengan uji Johansen, dengan melihat estimator maximum likelihood, didasarkan pada uji likelihood ratio $(L R)$. Jika nilai hitung $L R$ lebih besar dari niali kritis $L R$ maka kita menerima adanya kointegrasi sejumlah variabel dan sebaliknya jika nilai hitung $L R$ lebih kecil dari nilai kritisnya maka tidak ada kointegrasi.

\section{Vector Error Correction Model (VECM)}

Persoalan yang muncul didalam data time series adalah berkaitan dengan stasioneritas data time series dan kointegrasi. Jika data stasioner pada tingkat level maka digunakan model Vector Autoegression biasa (unrestricted $V A R)$. Sebaliknya jika data tidak stasioner pada level tetapi stasioner pada proses diferensi data, maka kita harus menguji apakah data mempunyai hubungan dalam jangka panjang atau tidak dengan melakukan uji kointegrasi. Apabila terdapat kointegrasi maka model yang digunakan adalah model Vector Correction Model (VECM). Model VECM ini merupakan model yang terestriksi (restricted VAR) karena adanya kointegrasi yang menunjukkan adalnya hubungan jangka panjang antar variable didalam system VAR.

\section{HASIL DAN PEMBAHASAN}

\section{Deteksi Stasioneritas: Uji Akar Unit pada Tingkat Level}

Data yang tidak stasioner bisa menyebabkan regresi yang lancung sehingga perlu dilakukan uji stasioneritas data. Hasil uji stasioneritas variabel-variabel dalam penelitian ditampilkan pada Tabel 1.

Dari hasil uji stasioneritas data pada tingkat level dengan intercept menghasilkan nilai absolut statistic Augmented Dickey-Fuller test $(A D F)$ lebih kecil dari nilai kritis MacKinnon pada setiap a-nya $(1 \%, 5 \%$, dan $10 \%)$ sehingga data-data tersebut termasuk data tidak stasioner. Hal ini berarti bahwa pasar modal di lima bursa efek negara-negara ASEAN dan Cina memiliki kemungkinan terintegrasi (mempunyai hubungan jangka panjang). Untuk mengetahui berapa derajat integrasi data-data tersebut perlu dilakukan uji pada tingkat diferensi sampai menemukan data yang stasioner. 
Tabel 1. Hasil Pengujian Unit Roots pada Tingkat Level Indeks Harga Saham Gabungan Lima Negara ASEAN dan Cina Periode waktu 1/2000 - 9/2012

\begin{tabular}{|c|c|c|c|}
\hline \multicolumn{2}{|c|}{ Augmented Dickey-Fuller test } & t-Statistic & Prob.* \\
\hline \multicolumn{2}{|c|}{ 1. Indeks harga saham gabungan Indonesia } & 0,622102 & 0,9900 \\
\hline \multicolumn{2}{|c|}{ 2. Indeks harga saham gabungan Malaysia } & 0,144733 & 0,9681 \\
\hline \multicolumn{2}{|c|}{ 3. Indeks harga saham gabungan Filipina } & $-2,034291$ & 0,2720 \\
\hline \multicolumn{2}{|c|}{ 4. Indeks harga saham gabungan Singapore } & $-0,517112$ & 0,8834 \\
\hline \multicolumn{2}{|c|}{ 5. Indeks harga saham gabungan Thailand } & 0,007199 & 0,9571 \\
\hline \multicolumn{2}{|c|}{ 6. Indeks harga saham gabungan Cina } & $-2,124324$ & 0,2355 \\
\hline \multirow[t]{3}{*}{ Test critical values: } & $1 \%$ level & $-3,473672$ & \\
\hline & $5 \%$ level & $-2,880463$ & \\
\hline & $10 \%$ level & $-2,576939$ & \\
\hline
\end{tabular}

*MacKinnon (1996) one-sided p-values.

Sumber: Hasil pengolahan data

\section{Deteksi Stasioneritas: Uji derajat integrasi (Uji Akar Unit pada Tingkat 1st Differens}

Uji stasioner pada tingkat level di atas menunjukkan hasil bahwa data tidak stasioner. Hasil uji stasioneritas pada tingkat diferensi pertama data indeks harga saham gabungan di lima bursa efek negara ASEAN dan Cina diperlihatkan pada Tabel 2 .

Hasil uji memperlihatkan bahwa uji stasioneritas tingkat diferensi pertama menghasilkan data stasioner karena nilai absolut ADF lebih besar dari nilai absolut statistic Mackinnon pada berbagai tingkat kepercayaan (1\%, 5\% dan 10\%) dengan intercept. Hal ini berarti bahwa indeks harga saham gabungan di lima bursa efek negara ASEAN dan Cina terintegrasi pada derajat pertama. Hal ini juga bisa berarti bahwa pasar modal di bursa efek lima negara ASEAN dan Cina mempunyai hubungan jangka panjang.

\section{Uji Kointegrasi: Uji Johansen}

Untuk mengetahui ada tidaknya kointegrasi, dilakukan pengujian dengan uji Johansen. Hasil pengujiannya dapat ditunjukkan pada Tabel 3.

Pada hasil tersebut, bandingkan nilai Trace Statistic dengan nilai kritis pada tingkat keyakinan $5 \%$ dan atau $1 \%$. Ternyata hanya pada baris pertama saja yang nilai Trace Statistic-nya lebih besar dibanding nilai kritis pada tingkat keyakinan 5\% maupun 1\%, sehingga dapat disimpulkan bahwa terdapat persamaan kointegrasi yang terbentuk.

\section{Estimasi Vector Error Correction Model (VECM)}

Hasil estimasi VECM ditampilkan pada Tabel 4 dalam Lampiran

Hasil uji stasioneritas diperoleh hasil bahwa uji stasioneritas data pada tingkat level menghasilkan data tidak stasioner dan pada uji

Tabel 2. Hasil Uji Stasioneritas Pada Tingkat 1st Differens Indeks Harga Saham Gabungan Lima Negara ASEAN dan Cina Periode waktu 1/2000 - 1/2012

\begin{tabular}{lccc}
\hline \multicolumn{1}{c}{ Augmented Dickey-Fuller test statistic } & t-Statistic & Prob. $^{*}$ \\
\hline 1. Indeks harga saham gabungan Indonesia & $-10,83020$ & 0,0000 \\
2. Indeks harga saham gabungan Malaysia & $-10,65885$ & 0,0000 \\
3. Indeks harga saham gabungan Philipina & $-11,90418$ & 0,0000 \\
4. Indeks harga saham gabungan Singapore & & $-12,26966$ & 0,0000 \\
5. Indeks harga saham gabungan Thailand & $1 \%$ level & $-11,82359$ & 0,0000 \\
6. Indeks harga saham gabungan Cina & 5\% level & $-6,464456$ & 0,0000 \\
Test critical values: & 10\%level & $-3,474265$ & \\
& & $-2,880722$ & \\
\hline
\end{tabular}

*MacKinnon (1996) one-sided p-values.

Sumber: Hasil pengolahan data 
Tabel 3. Uji Kointegrasi Johansen

\begin{tabular}{ccccc}
\hline $\begin{array}{c}\text { Hypothesized } \\
\text { No. of CE(s) }\end{array}$ & Eigenvalue & $\begin{array}{c}\text { Trace } \\
\text { Statistic }\end{array}$ & $\begin{array}{c}\text { 5 Percent } \\
\text { Critical Value }\end{array}$ & $\begin{array}{c}\text { 1 Percent } \\
\text { Critical Value }\end{array}$ \\
\hline None ** & 0,282931 & 103,7835 & 94,15 & 103,18 \\
At most 1 & 0,147176 & 54,56121 & 68,52 & 76,07 \\
At most 2 & 0,083479 & 30,99938 & 47,21 & 54,46 \\
At most 3 & 0,066097 & 18,09823 & 29,68 & 35,65 \\
At most 4 & 0,048144 & 7,977511 & 15,41 & 20,04 \\
\hline
\end{tabular}

$\left.{ }^{* * *}\right)$ denotes rejection of the hypothesis at the $5 \%(1 \%)$ level. Trace test indicates 1 cointegrating equation(s) at both $5 \%$ and $1 \%$ levels

Sumber: Hasil pengolahan data

stasioneritas tingkat diferensi pertama menghasilkan data stasioner. Berdasarkan hasil uji stasioneritas tersebut, maka untuk mengetahui terdapatnya integrasi pasar modal kawasan ASEAN dan Cina, model yang digunakan adalah model Vector Correction Model (VECM). Panjang kelambanan optimal adalah 4 berdasarkan criteria AIC dan SIC.

Dari uji ini akan diketahui adanya integrasi atau tidak antarpasar modal di kawasan ASEAN dan Cina. Pembuktian dilakukan dengan dua cara. Pertama, membandingkan F statistic dengan signifikansinya. Jika nilai F statistiknya lebih besar daripada tingkat signifikansi berbagai tingkat kepercayaannya $(1 \%, 5 \%$ dan $10 \%)$, maka berarti terjadi integrasi, tetapi apabila kejadian sebaliknya, yaitu nilai F statistiknya lebih kecil daripada tingkat signifikansi berbagai tingkat kepercayaannya $(1 \%, 5 \%$ dan $10 \%$ ), maka tidak terjadi integrasi. Kedua, dengan membandingkan nilai t-hitung dengan tingkat signifikansi. Jika nilai t statistiknya lebih besar daripada tingkat signifikansi berbagai tingkat kepercayaannya $(1 \%, 5 \%$, dan $10 \%)$, maka berarti terjadi integrasi, tetapi apabila kejadian sebaliknya, yaitu nilai $t$ statistiknya lebih kecil daripada tingkat signifikansi berbagai tingkat kepercayaannya $(1 \%, 5 \%$, dan $10 \%)$, maka tidak terjadi integrasi.

Dari Tabel 4 dalam Lampiran dapat dilihat bahwa berdasarkan uji F, pasar modal Indonesia, Malaysia, Singapura, Thailand dan Cina memiliki nilai $F$ hitung yang lebih besar daripada $\mathrm{F}$ tabelnya pada tingkat signifikansi 0,05 . Ini berarti pasar modal di lima Negara tersebut terintegrasi dengan pasar modal yang lain di dalam kawasan tersebut. Berdasarkan uji t-hitung, dapat dianalisis untuk masing-masing pasar modal.
Pada persamaan pasar modal Indonesia, semua variabel, yaitu pasar modal Malaysia, Singapura, Thailand, Pilipina dan Cina memiliki $t$ hitung yang lebih besar daripada $t$ tabel. Artinya adalah bahwa Pasar modal Indonesia dipengaruhi oleh semua pasar modal di kawasa ASEAN dan Cina.

Pada persamaan pasar modal Singapura, hanya pasar modal Cina yang memiliki thitung yang lebih besar daripada $t$ tabel. Artinya adalah bahwa pasar modal Singapura hanya dipengaruhi oleh pasar modal Cina.

Pada persamaan pasar modal Kualalumpur, hanya pasar modal Singapura yang memiliki $t$ hitung yang lebih besar daripada $t$ tabel. Artinya adalah bahwa pasar modal Kualalumpur hanya dipengaruhi oleh pasar modal Singapura.

Pada persamaan pasar modal Thailand, hanya pasar modal Singapura yang memiliki $t$ hitung yang lebih besar daripada $t$ tabel. Artinya adalah bahwa pasar modal Thailand hanya dipengaruhi oleh pasar modal Singapura.

Pada persamaan pasar modal Pilipina, tidak ada variabel yang memiliki thitung yang lebih besar daripada $t$ tabel. Artinya adalah bahwa pasar modal Pilipina tidak dipengaruhi oleh pasar modal lain dalam satu kawasan tersebut.

Pada persamaan pasar modal Cina, hanya pasar modal Singapura yang memiliki t hitung yang lebih besar daripada $t$ tabel. Artinya adalah bahwa pasar modal Cina hanya dipengaruhi oleh pasar modal Singapura.

Selain itu, dari hasil analisis data di atas dapat dilihat bahwa pasar modal Singapura dipengaruhi oleh pasar modal Cina, dan pasar modal Cina dipengaruhi oleh pasar modal Singapura. 
Persamaan integrasi pasar modal yang terbentuk adalah sebagai berikut :

(1) Pasar modal Indonesia

Indonesia $=-21,62006+0,242707$ Singapura + [ 9,59061]

0,778687Malaysia + 0,053189 Pilipina + [ 9,71677] [1,72395]

0,828902 Thailand $+0,191769$ Cina

[ 4,88062] [ [7,51261]

(2) Pasar modal Singapura

Singapura $=25,14062+0,120635$ Cina

[3,87640]

(3) Pasar modal Malaysia

Malaysia $=-11,95322+1,291228$ Singapura [2,32143]

(4) Pasar modal Thailand

Thailand $=0,941412+0,629234$ Singapura

[2,14687]

(5) Pasar Modal Cina

Cina $=4,553462+0,176140$ Singapura

[1,95839]

Apabila keterkaitan pengaruh antarvariabel atau antarpasar modal tersebut ditunjukkan dalam suatu diagram, maka akan terlihat seperti gambar 1.

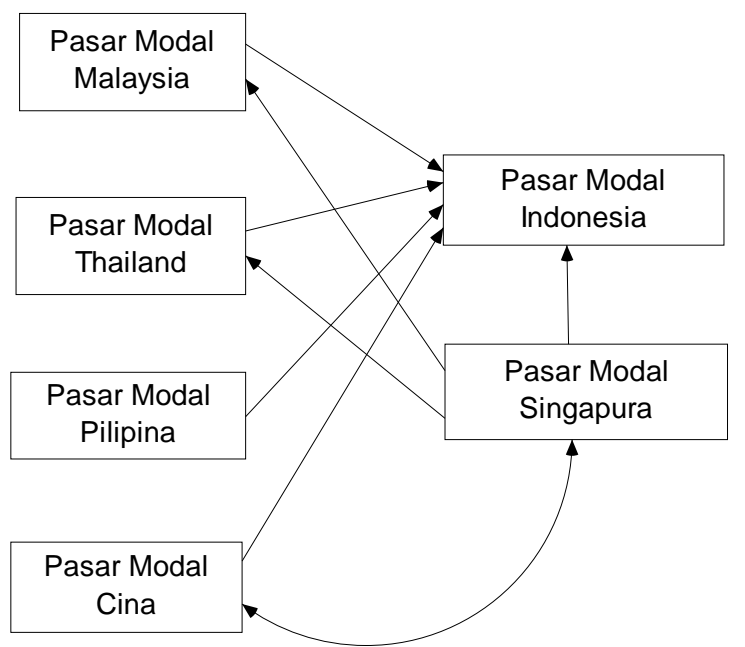

Gambar 1. Keterkaitan Pengaruh Antar Pasar Modal Kawasan ASEAN dan Cina

\section{Pembahasan}

Pengaruh pasar modal Malaysia, Philipina, Singapura, Thailand dan Cina terhadap pasar modal Indonesia adalah positif. Pengaruh positif ini berarti ketika pasar modal (IHSG)
Malaysia, Filipina, Singapura, Thailand dan Cina mengalami kenaikan maka akan berpengaruh positif terhadap pasar modal (IHSG) di Indonesia atau sebaliknya ketika pasar modal (IHSG) Malaysia, Filipina, Singapura, Thailand, dan Cina mengalami penurunan maka pasar modal Indonesia akan mengalami penurunan yang signifikan juga.

Pasar modal Cina berpengaruh positif terhadap pasar modal Singapura. Sebaliknya, pasar modal Singapura juga berpengaruh positif terhadap pasar modal Cina. Sehingga antara kedua pasar terjadi integrasi yang lengkap, yaitu saling pengaruh mempengaruhi.

Dari semua pasar modal di kawasan ASEAN dan Cina, hanya pasar modal Singapura yang mempengaruhi semua pasar modal secara positif. Artinya apabila pasar modal Singapura mengalami kenaikan, maka akan berpengaruh meningkatkan pasar modal kawasan. Sebaliknya, apabila pasar modal Singapura mengalami penurunan, maka pasar modal kawasan juga akan mengalami penurunan.

Hasil pembuktian di atas diperoleh beberapa point penting. Pertama, bahwa masingmasing pasar modal baik di Malaysia, Pilipina, Singapura, Thailand dan Cina berpengaruh positif secara signifikan terhadap pasar modal Indonesia. Di sisi yang lain, pasar modal Indonesia tidak mempunyai pengaruh yang signifikan terhadap pasar modal negara-negara yang lain. Ini dapat diartikan bahwa, pasar modal Indonesia ada pada posisi yang rentan, mudah terpengaruh oleh gejolak pasar modal yang terjadi di negara-negara lain khususnya dalam satu kawasan ASEAN dan Cina.

Kedua, di sisi yang lain, pasar modal Singapura berpengaruh positif secara signifikan terhadap pasar modal-pasar modal yang lain yaitu Indonesia, Malaysia, Thailand dan Cina selain Pilipina. Posisi pasar modal Singapura berada pada posisi yang kuat, sebagai acuan pasar modal yang lain dalam satu kawasan. Dalam satu kawasan, hanya pasar modal Cina yang mempengaruhi pasar modal Singapura. Dapat dikatakan bahwa pasar modal Singapura dan Cina terjadi integrasi yang lengkap. Antara keduanya saling mempengaruhi dan saling dipengaruhi.

Dari sekian banyak pasar modal yang di- 
analisis, pasar modal Pilipina hanya mempengaruhi pasar modal Indonesia, dan tidak ada pasar modal lain yang mempengaruhinya. Hal ini dapat dikatakan bahwa pasar modal Pilipina relative lebih tersegmentasi, dipengaruhi oleh gejolak di dalam negeri saja. Hal ini kemungkinan karena investor asing yang relative sedikit dan kapitalisasi pasar masih kecil.

Dari semua pasar modal yang dianalisis, pasar modal Indonesia ada pada posisi yang paling rentan. Kondisi pasar modal Indonesia yang rentan ini dimungkinkan karena transaksi yang terjadi pada pasar modal Indonesia didominasi oleh investor asing. (Nurhayati, 2012). Tercatat investor asing saat ini memegang sekitar 60 persen dari total market capitalization, maka hal ini harus menjadi perhatian lebih. Karena, jika pihak asing secara serentak melakukan rush dan dananya dilarikan ke luar negeri maka yang akan terjadi adalah selain terjadi crash di pasar modal Indonesia dengan penurunan Indeks Harga Saham Gabungan yang signifikan, maka juga akan terjadi capital outflow yang besar dan juga akan mempengaruhi neraca pembayaran Indonesia.

Selain itu, karakteristik pasar modal Indonesia yang didominasi oleh beberapa penyandang dana yang sangat besar, sementara volume pasarnya masih kecil membuat pasar modal Indonesia rentan terhadap pengendalian dari pelaku pasar. (infogue.com, 2011) dalam Nurhayati (2012). Menurut pengamat hukum pasar modal Indra Safitri, (infogue.com, 2011), karakteristik tersebut mengakibatkan sangat mungkin merosotnya atau melonjaknya indeks harga saham gabungan (IHSG) dalam waktu yang sangat cepat juga akibat dimanipulasi oleh pelaku pasar. Ini bisa dicermati dari saat indeks bursa regional hanya turun lima persen, IHSG bisa terjun bebas hingga 10 persen. Demikian juga saat semuanya naik, IHSG bisa naik berkali-kali lipat.

Karakteristik yang lain, investor lokal yang berperan di pasar modal Indonesia didominasi oleh kalangan institusi sedangkan investor lokal perorangan masih sangat kecil. Hal ini karena kurangnya pemahaman tentang pasar modal, dan masih kurangnya kegiatan sosialisasi dan edukasi pasar modal. Tandelilin menyebutkan bahwa jumlah investor di pasar modal Indonesia hanya berkisar di angka 200.000. (Suara Merdeka 2012) dalam Nurhayati (2012). Jumlah itu jauh tertinggal dibandingkan Singapura yang sudah mencapai 2 juta Sehingga apabila terjadi gejolak yang dilakukan oleh sebagian kecil dari pelaku pasar saja akan dapat menyebabkan pasar bergejolak lebih besar.

Jadi, dalam era globalisasi dewasa ini, untuk negara-negara yang memiliki pasar modal yang rentan seperti Indonesia bisa menyebabkan pasar modalnya tenggelam sehingga akan jarang investor yang mau menanamkan investasinya. Untuk menghindari masalah ini adalah dengan lebih banyak menarik investor domestik (nasional) untuk masuk menjadi investor di pasar modal Indonesia karena sampai sekarang investor domestik Indonesia masih dinilai kecil baru sekitar 40 persen dibandingkan dengan peran investor asing. Selain itu Bapepam dan BEI pada saat IPO sebuah emiten berlangsung bebar-benar mengawasi bahwa saham dimiliki oleh publik, dan bukannya oleh segelintir orang ataupun pemegang saham mayoritas. Sehingga penyebaran saham bisa merata.

\section{SIMPULAN}

Berdasarkan hasil penelitian dan analisa data, maka dapat disimpulkan bahwa berdasarkan uji stasioneritas dan uji kointegrasi dapat diambil kesimpulan bahwa dalam jangka panjang terjadi integrasi pasar modal. Hal ini dapat ditunjukkan dengan uji stasioneritas unit root pada tingkat level yang tidak stasioner, sehingga harus dilakukan uji stasioneritas tingkat diferensial pertama yang akhirnya stasioner.

Dengan menggunakan analisis VECM (Vector Error Correction Model) diperoleh hasil bahwa pertama, masing-masing pasar modal baik di Malaysia, Pilipina, Singapura, Thailand dan Cina berpengaruh positif secara signifikan terhadap pasar modal Indonesia. Pasar modal Indonesia tidak mempunyai pengaruh yang signifikan terhadap pasar modal negara-negara yang lain. Kedua, pasar modal Singapura berpengaruh positif secara signifikan terhadap pasar modal-pasar modal yang lain yaitu Indonesia, Malaysia, Thailand dan Cina selain 
Pilipina. Ketiga, dalam satu kawasan, hanya pasar modal Cina yang mempengaruhi pasar modal Singapura. Pasar modal Singapura dan Cina terjadi integrasi yang lengkap. Antara keduanya saling mempengaruhi dan saling dipengaruhi. Keempat, pasar modal Pilipina hanya mempengaruhi pasar modal Indonesia, dan tidak ada pasar modal lain yang mempengaruhinya. Pasar modal Indonesia ada pada posisi yang rentan, mudah terpengaruh oleh gejolak pasar modal yang terjadi di negaranegara lain khususnya dalam satu kawasan ASEAN dan Cina. Posisi pasar modal Singapura berada pada posisi yang kuat, sebagai acuan pasar modal yang lain dalam satu kawasan. Pasar modal Singapura dan Cina terjadi integrasi yang lengkap. Antara keduanya saling mempengaruhi dan saling dipengaruhi. Pasar modal Pilipina relatif lebih tersegmentasi, dipengaruhi oleh gejolak di dalam negeri saja.

Saran. Dengan melihat hasil analisis dari penelitian ini, maka saran-saran yang diajukan, adalah bahwa Pemerintah diharapkan dapat menetapan kebijakan tentang pasar modal yang dapat mendorong investor domestik untuk lebih meningkatkan perannya sebagai investor untuk mengimbangi peran investor asing sehingga pasar modal Indonesia menjadi tidak rentan terhadap pengaruh dari luar. Investor tentunya harus memperhatikan implikasi dari terintegrasinya pasar yang tentunya akan berpengaruh terhadap prospek-prospek investasi baik di dalam negeri Indonesia maupun di negara-negara yang terintegrasi. Penelitianpenelitian tentang pasar modal internasional akan semakin menarik dengan semakin menyatunya perekonomian secara global. Integrasi pasar modal akan semakin luas tidak hanya dalam satu kawasan saja, tetapi penelitian selanjutnya dapat meneliti keterkaitan pasar modal-pasar modal di seluruh penjuru dunia

\section{DAFTAR PUSTAKA}

Adler, M. and Dumas, B. 1983. International Portfolio Selection and Corporate Finance: A Synthesis. Journal of Finance. 46: 925-984.
Assaf, A. 2003. Transmission of Stock Price Movements: The Case of GCC Stock Markets. Review of Middle East Economics and Finance. Vol. 1. No. 2.

Bekaert, G. and Harvey, C. 1995. Time-Varying World Market Integration. Journal of Finance. 50: 403-444.

Bierens, H.J. 2006. Cointegration Analysis. Pennsylvania State University.

Bodie, Z., Kane, A., and Marcus, A.J. 2005. Investment. 6th Edition. Diterjemahkan oleh Zuliani Dalimonte. Jakarta: Penerbit Salemba Empat.

Brooks, R. and Negro, M.D. 2002. The Rise in Comovement Across National Stock Market: Market Integration or IT Bubble? Federal Roserve Bank of Atlanta Working Paper 2002-17a, September.

Buckberg, E. 1995. Emerging Sock Markets and International Asset Pricing. The World Bank Economic Review. 9: 51-74.

Choudhry, T. Lu, L., and Peng, K. 2007. Common Stochastic Trends among Far East Stock Prices: Effects of the Asian Financial Crisis. International Review of Financial Analysis.16: 242-261.

Darrat, A.F., Khaled, E., and Hakim S.R. 2000. On the Integration of Emerging Stock Markets in The Middle East. Journal of Economic Development. 25: 119-129.

Endri. 2009. Integrasi Pasar Saham Kawasan Perdagangan Bebas ASEAN- China: Analisis Kointegrasi Pasar Saham ASEAN-5 Plus China dan Implikasinya Terhadap Pengelolaan Portofolio Internasional. Integritas - Jurnal Manajemen Bisnis. Vol. 2. No. 2: 121 - 139 .

Febrian, E., and Herwany, A. 2007. Co-integration and Causality among Jakarta Stock Exchange, Singapore Stock Exchange, and Kuala Lumpur Stock Exchange. MPRA Paper. No. 9637.

Hady, D. H. 2004. Ekonomi Internasional: Teori dan Kebijakan Perdagangan Internasional. Jakarta: Ghalia Indonesia. 
Husnan, S. 2004. Dasar-dasar Teori Portofolio dan Analisis Sekuritas, Edisi Revisi, UPP AMP YKPN Yogyakarta.

Indonesian CRI. 2010. Kronologi Proses Pembentukan Zona Perdagangan Bebas TiongkokASEAN (CAFTA). http://indonesian. cri.cn/481/2010/01/07/1s106422.htm. diunduh pada tanggal 1 Juni 2010

Jian, Y., Kolar, J.W., and Insik, M. 2003. Stock Market Integration and Financial Crisis: The Case of Asia. Applied Financial Economics.13: 477-486.

Jorion, P. and Schwartz, E. 1986. Integration vs. Segmentation in The Canadian Stock Market. Journal of Finance. 41: 603-616.

Kasa, K.1992. Common Stochastic Trends in International Stock Markets. Journal of Monetary Economics. 29: 95-124.

Kearney, C. and Lucey, B. 2004. International Equity Market Integration: Theory, Evidence and Implications. International Review of Financial Analysis.13: 571-583.

Liaw, K.T. 2005. Capital market. ThomsonSouthwestern.

Marashdeh, H. 2005. Stock Market Integration in the MENA Region: An Application of The ARDL Bounds Testing Approach. Economics Working Papers. No. 05-27. School of Economics, University of Wollongong, NSW, Australia.

Marashdeh, H. and Shrestha, M.B. 2010. Stock Market Integration in the GCC Countries. International Research Journal of Finance and Economics. Issue 37.

Narayan, P., Smith, R., and Nandha, M. 2004. Interdependence and Dynamic Linkages Between The Emerging Stock Markets of South Asia. Accounting and Finance. 44: 419-439.
Neaime, S. 2002. Liberalization and Financial Integration of MENA Stock Markets. A Paper. Prepared at The ERF's 9th Annual Conference on "Finance and Banking", United Arab Emirates.

Nurhayati, M. 2012. Analisis Integrasi Pasar Modal Kawasan ASEAN dalam Rangka Menuju Masyarakat Ekonomi ASEAN. Proseding. Seminar Nasional, Semarang.

Onay, C. 2007. Cointegration Analysis of Bovespo and Istambul Stock Exchanges. Oxford Business and Economics Conference. Oxford University. United Kingdom.

Saini, A., Azali, M. Habibullah, M.S., and Matthews, K. G. 2002. Financial Integration and The ASEAN-5 Equity Markets. Applied Economics. 34: 2283-2289.

Solink, B. 1974. An Equilibrium Model of The International Capital Market. Journal of Economic Theory. 8: 500-524.

Stulz, R.M.1981. A model of International Assets Pricing. Journal of Financial Economics. 9: 383-406.

Von Furstenberg, G. M. and Jeon, B. N. 1989. International Stock Price Movements: Links and Messages. Brookings Papers on Economic Activity.1: 125-179.

Widarjono, A. 2007. Ekonometrika Teori dan Aplikasi. Edisi kedua. Yogyakarta: Penerbit Ekonisia Fakultas Ekonomi UII.

http://ekonomi-indonesia-bisnis.infogue.com/ transaksi_bei_rentan_pelanggaran, Diunduh 18 Mei 2012.

http:/ / www.ditjenkpi.go.id

http:/ / www.finance.yahoo.com

http://www.suaramerdeka.com/v1/index.php /read/cetak/2012/04/17/183508/Invest or-Asing-Dominasi-Pasar-ModalIndonesia. Diunduh 18 Mei 2012. 


\section{LAMPIRAN}

Tabel 4. Hasil Estimasi VECM

\begin{tabular}{|c|c|c|c|c|c|c|}
\hline \multirow{2}{*}{$\begin{array}{c}\text { INDEPENDENT } \\
\text { VARIABLE }\end{array}$} & \multicolumn{6}{|c|}{ DEPENDENT VARIABLE } \\
\hline & IHSG & IST & KLSE & MANILA & SET & SHANGHAI \\
\hline IHSG & $\begin{array}{r}0,182963 \\
(0,04408) \\
{[4,15042]}\end{array}$ & $\begin{array}{r}0,048692 \\
(0,08949) \\
{[0,54408]}\end{array}$ & $\begin{array}{c}0,023012 \\
(0,03948) \\
{[0,58295]}\end{array}$ & $\begin{array}{r}-0,012648 \\
(0,08366) \\
{[-0,15118]}\end{array}$ & $\begin{array}{r}-0,002390 \\
(0,01257) \\
{[-0,19011]}\end{array}$ & $\begin{array}{r}0,024885 \\
(0,02249) \\
{[1,10637]}\end{array}$ \\
\hline IST & $\begin{array}{r}0,242707 \\
(0,02531) \\
{[9,59061]}\end{array}$ & $\begin{array}{l}0,026974 \\
(0,01247) \\
{[2,16386]}\end{array}$ & $\begin{array}{r}1,291228 \\
(0,55622) \\
{[2,32143]}\end{array}$ & $\begin{array}{r}0,015213 \\
(0,09770) \\
{[0,15571]}\end{array}$ & $\begin{array}{r}0,629234 \\
(0,29309) \\
{[2,14687]}\end{array}$ & $\begin{array}{r}0,176140 \\
(0,08994) \\
{[1,95839]}\end{array}$ \\
\hline KLSE & $\begin{array}{r}0,778687 \\
(0,08014) \\
{[9,71677]}\end{array}$ & $\begin{array}{c}0,130082 \\
(0,10911) \\
{[1,19226]}\end{array}$ & $\begin{array}{l}1,122065 \\
(0,60010) \\
{[1,86978]}\end{array}$ & $\begin{array}{r}-0,133968 \\
(0,20653) \\
{[-0,64868]}\end{array}$ & $\begin{array}{r}0,722292 \\
(0,61123) \\
{[1,18171]}\end{array}$ & $\begin{array}{r}-0,014740 \\
(0,05567) \\
{[-0,26479]}\end{array}$ \\
\hline MANILA & $\begin{array}{r}0,053189 \\
(0,03085) \\
{[1,72395]}\end{array}$ & $\begin{array}{r}-0,058013 \\
(0,32208) \\
{[-0,18012]}\end{array}$ & $\begin{array}{r}-0,182467 \\
(0,28841) \\
{[-0,63266]}\end{array}$ & $\begin{array}{c}0,179179 \\
(0,09187) \\
{[1,95040]}\end{array}$ & $\begin{array}{r}-0,121598 \\
(0,09108) \\
{[-1,33510]}\end{array}$ & $\begin{array}{r}-0,054751 \\
(0,16433) \\
{[-0,33317]}\end{array}$ \\
\hline SET & $\begin{array}{r}0,828902 \\
(0,16984) \\
{[4,88062]}\end{array}$ & $\begin{array}{c}0,148608 \\
(0,31622) \\
{[0,46995]}\end{array}$ & $\begin{array}{r}-0,357198 \\
(0,28317) \\
{[-1,26145]}\end{array}$ & $\begin{array}{r}0,009850 \\
(0,08942) \\
{[0,11016]}\end{array}$ & $\begin{array}{l}0,162495 \\
(0,09020) \\
{[1,80158]}\end{array}$ & $\begin{array}{r}0,002972 \\
(0,16134) \\
{[0,01842]}\end{array}$ \\
\hline SHANGHAI & $\begin{array}{r}0,191769 \\
(0,02553) \\
{[7,51261]}\end{array}$ & $\begin{array}{r}0,120635 \\
(0,03112) \\
{[3,87640]}\end{array}$ & $\begin{array}{r}-0,014615 \\
(0,15045) \\
{[-0,09714]}\end{array}$ & $\begin{array}{c}0,007003 \\
(0,04751) \\
{[0,14739]}\end{array}$ & $\begin{array}{r}-0,044872 \\
(0,04792) \\
{[-0,93635]}\end{array}$ & $\begin{array}{c}0,014064 \\
(0,00448) \\
{[3,13585]}\end{array}$ \\
\hline C & $\begin{array}{r}-21,62006 \\
(19,1397) \\
{[-1,12959]}\end{array}$ & $\begin{array}{r}25,14062 \\
(10,0854) \\
{[2,49277]}\end{array}$ & $\begin{array}{r}-11,95322 \\
(9,03123) \\
{[-1,32354]}\end{array}$ & $\begin{array}{r}-0,475521 \\
(2,85196) \\
{[-0,16674]}\end{array}$ & $\begin{array}{r}0,941412 \\
(2,87669) \\
{[0,32726]}\end{array}$ & $\begin{array}{r}4,553462 \\
(5,14584) \\
{[0,88488]}\end{array}$ \\
\hline R-squared & 0,500135 & 0,224350 & 0,493315 & 0,498312 & 0,254311 & 0,032042 \\
\hline Adj. R-squared & 0,452353 & 0,150207 & 0,444882 & 0,450356 & 0,183032 & 0,060484 \\
\hline Sum sq. resids & 149080,5 & 1832415, & 1469363, & 146528,1 & 6599400, & 477031,2 \\
\hline S.E. equation & 33,10861 & 116,0760 & 103,9430 & 32,82396 & 220,2839 & 59,22484 \\
\hline F-statistic & 10,46717 & 5,025911 & 5,18549 & 1,39113 & 5,567829 & 5,346300 \\
\hline Log likelihood & $-730,4612$ & $-918,6290$ & $-902,0686$ & $-729,1661$ & $-1014,730$ & $-817,6934$ \\
\hline Akaike AIC & 9,926150 & 12,43505 & 12,21425 & 9,908881 & 13,71640 & 11,08925 \\
\hline Schwarz SC & 10,20714 & 12,71605 & 12,49524 & 10,18987 & 13,99739 & 11,37024 \\
\hline Mean dependent & 4,444200 & 23,49173 & 5,755400 & 5,581067 & 1,583000 & 3,930000 \\
\hline S.D. dependent & 44,73946 & 125,9175 & 139,5091 & 44,27416 & 243,7139 & 57,51113 \\
\hline
\end{tabular}

Keterangan:

- Angka pada baris pertama setiap variable menunjukkan koefisien regresi

- Angka pada kurung pertama menunjukkan standard error

- Angka dalam kurung kedua menunjukkan nilai t hitung

- $\quad F$ tabel $(n=120 ; k=5 ; a=0,05)=4,40$

- $\quad t$ tabel $(n=120 ; a=0,05)=1,658 ; t$ tabel $(n=120 ; a=0,01)=2,358$

Sumber: hasil pengolahan data 